\title{
Particle-bound Polycyclic Aromatic Hydrocarbons (pPAHs) in Merida, Mexico
}

Aerosol and Air Quality Research

\section{OPEN ACCESS}

Received: June 3, 2020

Revised: December 13, 2020

Accepted: December 21, 2020

* Corresponding Author:

harryalvarez@ciencias.unam.mx

\section{Publisher:}

Taiwan Association for Aerosol Research

ISSN: $1680-8584$ print

ISSN: 2071-1409 online

Copyright: The Author(s). This is an open access article distributed under the terms of the Creative Commons Attribution License (CC BY 4.0), which permits unrestricted use, distribution, and reproduction in any medium, provided the original author and source are cited.

\section{Harry Alvarez-Ospina ${ }^{1 *}$, Sofia Giordano ${ }^{1}$, Luis A. Ladino ${ }^{2}$, Graciela B. Raga ${ }^{2}$, Joshua I. Muñoz-Salazar ${ }^{1,2}$, Martha Leyte-Lugo ${ }^{3}$, Daniel Rosas ${ }^{4}$, Giovanni Carabali ${ }^{5}$}

\author{
${ }^{1}$ Facultad de Ciencias, Universidad Nacional Autónoma de México, Ciudad de México, México \\ ${ }^{2}$ Centro de Ciencias de la Atmósfera, Universidad Nacional Autónoma de México, Ciudad de \\ México, México \\ ${ }^{3}$ Catedrática CONACYT Comisionada a la Universidad Autónoma Metropolitana-Xochimilco, \\ Ciudad de México, México \\ ${ }^{4}$ Facultad de Química, Universidad Autónoma de Yucatán, Mérida, México \\ ${ }^{5}$ Instituto de Geofísica, Universidad Nacional Autónoma de México, Ciudad de México, México
}

\section{ABSTRACT}

This study focuses on the air quality evaluation of Merida, a medium-size city located in the Yucatan Peninsula with a significant population growth in recent years. Particle-bound Polycyclic Aromatic Hydrocarbons (pPAHs) were quantified with a real time sensor during a six-month period during the dry season (October 2017 to March 2018). The pPAHs diurnal and monthly characteristics, as well as their potential sources were determined. The total pPAHs concentrations ranged from $7 \mathrm{ng} \mathrm{m}^{-3}$ to $170 \mathrm{ng} \mathrm{m}^{-3}$, with an average value of $19 \pm 11 \mathrm{ng} \mathrm{m}^{-3}$. A seasonal trend was observed, albeit not complete, indicating that pPAHs concentrations were higher during the colder months (October through January) than in February and March. The diurnal cycle showed a bimodal behavior similar to those found for carbon monoxide (CO), nitrogen oxides (NOx) and black carbon (BC) (estimated from absorption coefficient), indicating that burning of fossil fuels from vehicular traffic is the likely source of the pPAHs emitted in Merida. Moreover, atypical nocturnal values were observed, where the high pPAHs concentration could be associated with the burning of solid waste. The average pPAHs concentration obtained in this study $(19 \pm$ $11 \mathrm{ng} \mathrm{m}^{-3}$ ) were found to be lower than the values measured in two other sites in Mexico City (32 $\mathrm{ng} \mathrm{m}^{-3}$ and $50 \mathrm{ng} \mathrm{m}^{-3}$ ), Boston $\left(29 \mathrm{ng} \mathrm{m}^{-3}\right)$, Los Angeles $\left(88.3 \mathrm{ng} \mathrm{m}^{-3}\right.$ ) and Quito $\left(220 \mathrm{ng} \mathrm{m}^{-3}\right)$.

Keywords: Air pollution, Aerosol particles, Polycyclic aromatic hydrocarbons, Photoelectric aerosol sensor

\section{INTRODUCTION}

Polycyclic aromatic hydrocarbons (PAHs) are ubiquitous organic compounds composed of two or more fused aromatic rings found in soil, water, and air (Phan et al., 2019). PAHs with two or three aromatic rings exist predominantly in the gas phase (light PAHs), whereas those with four or more aromatic rings (heavy PAHs) tend to be adsorbed onto airborne particles and they are known as particle-bound PAHs (Baek et al., 1991; Choi et al., 2012; Jamhari et al., 2014; Nguyen et al., 2018).

PAHs are emitted from both natural and anthropogenic sources. Natural sources include forest fires and volcanic eruptions (Stracquadanio et al., 2003; Ravindra et al., 2008; Kim et al., 2011; Choi, 2014; Nguyen et al., 2018; Phan et al., 2019), while anthropogenic sources are related to activities such as the incomplete combustion of organic materials including wood, fossil fuels and petroleum products, industrial emissions, tobacco smoke, emissions from shipping, and fireworks (Maliszewska-Kordybach, 1999; Kong et al., 2010; Choi et al., 2012; Tobiszewski and Namiesnik, 
2012; Pongpiachan et al., 2015; Abdel-Shafy and Mansour, 2016; Pongpiachan et al., 2017; Syed et al., 2017; Sulong et al., 2019).

Air pollution studies focused on PAHs have received more attention in recent years, given that some of these compounds are highly mutagenic, carcinogenic, and toxic (Amagai et al., 1999; Ohura et al., 2004; Srogi, 2007; Sarigiannis et al., 2015; Phan et al., 2019; Sulong et al., 2019). PAHs have been shown to impair pulmonary function, cause asthmatic and thrombotic effects in people with coronary heart problems, increased lung cancer risk, cause skin irritation and inflammation, and have negative effects on the reproductive and immune systems since they have the potential to interfere with the hormonal system (Tsapakis and Stephanou, 2005; Unwin et al., 2006; John et al., 2009; Delfino et al., 2009; Zhang et al., 2009; Garcia-Suastegui et al., 2011; Sarigiannis et al., 2015; Sulong et al., 2019). Sixteen PAHs have been identified as priority pollutants by the United States Environmental Protection Agency (U.S. EPA), eight of them considered as probable carcinogens: benzo[a]anthracene, benzo[b]fluoranthene, benzo[k]fluoranthene, benzo[a]pyrene, dibenzo[a,h]anthracene, indeno[1,2,3-cd]pyrene, benzo[g,h,i]perylene, and chrysene (Menzie et al., 1992; Srogi, 2007). Particularly, benzo[a]pyrene has been identified as being highly carcinogenic by the International Agency for Research Cancer (IARC) (Nisbet and LaGoy, 1992; Kuo et al., 1998; Wang et al., 2002).

Since PAHs have important effects on human health, numerous studies have been carried out around the world in order to determine their concentrations, variability, and emission sources. The first pPAHs study was conducted in Mexico by Salazar et al. (1991), in the Northwestern sector of Mexico City, near the oil refinery "18 de Marzo" in Azcapotzalco, during January 1990. Ambient samples analyzed by capillary Gas Chromatography, showed the presence of 11 PAHs, mainly those with 2 to 5 aromatic rings, such as naphthalene, acenaphthylene, fluorene, phenanthrene, anthracene, fluoranthene, pyrene, benzo[a]anthracene, chrysene, benzo[b]fluoranthene, benzo[k]fluoranthene and benzo[a]pyrene (Salazar et al., 1991). Velasco et al. (2004) later present measurements of personal exposure to pPAHs in different outdoor and indoor environments and along roadways in Mexico City during December 2001 using Photoelectric Aerosol Sensor (PAS). The results show that most of the personal exposure in Mexico City to pPAHs comes from indoor cigarette smoke and outdoor diesel engines. The highest exposures were found in ambient air near traffic sources, mainly in sites with many diesel vehicles such as urban transfer bus stations. However, high levels of exposure were also found on all the monitored roadways, indicating that pPAHs pollution is a problem throughout the entire city (Velasco et al., 2004).

Marr et al. (2004) carried out a study in 2002, employing the PAS, to describe the ambient and occupational pPAHs concentrations associated with vehicular traffic and facilities using diesel vehicles on three routes in Mexico City. The median total pPAHs concentrations in Mexico City's roadways were in a range between 60 to $910 \mathrm{ng} \mathrm{m}^{-3}$, with an average of $310 \mathrm{ng} \mathrm{m}^{-3}$. The high pPAHs concentrations found on Mexican roadways are likely due to a combination of old dieselpowered vehicles and the city's notoriously dirty light-duty vehicle fleet, $50 \%$ of which lacked catalytic converters in 1998 (Marr et al., 2004).

In another study carried out during the Mexico City Metropolitan Area campaign (MCMA-2003) in 2003, Marr et al. (2006) reported that during the morning rush hour, pPAHs concentrations rise to a maximum of $\sim 110 \mathrm{ng} \mathrm{m}^{-3}$ between 07:30-08:00 and then decrease throughout the remainder of the morning to $\sim 20 \mathrm{ng} \mathrm{m}^{-3}$ in the afternoon. Overnight concentrations rise as high as $50 \mathrm{ng} \mathrm{m}^{-3}$. Marr et al. (2006) quantified pPAHs by three methods: filter collection and analysis by gas chromatography/mass spectrometry (GC/MS), aerosol photoionization using PAS, and aerosol mass spectrometry (AMS). GC/MS analysis allows pPAHs chemical speciation; however, it requires lengthy sampling periods (longer than eight hours) to ensure quantification. Moreover, pPAHs concentrations from filter samples can be underestimated due to volatilization and chemical reactions of the compounds over the filters (Grosjean, 1983; Salazar et al., 1991; Marr et al., 2006; Ladino et al., 2018). In contrast, PAS is a sensitive online technique that detects total surface pPAHs concentrations that allow the determination of diurnal variation. These shorter timescales can be very important for exposure and dosage (Marr et al., 2006). Lastly, the AMS technique provides speciation by molecular weight and size distributions. Thus, the three methods generally report similar trends of the same order of magnitude, although with certain differences due to methodological limitations, e.g., pPAHs transformation and/or uncertainties in calibration (Marr et al., 2006). 
During the MILAGRO campaign (Megacity Initiative: Local And Global Research Observations) in 2006, Thornhill et al. (2008) reported pPAHs concentrations measured with the PAS. The results indicated that during the morning rush hour (06:30-08:30), pPAHs concentrations increased to a maximum of $\sim 250 \mathrm{ng} \mathrm{m}^{-3}$, and then decreased during the morning to $\sim 20 \mathrm{ng} \mathrm{m}^{-3}$, with average concentrations of $50 \mathrm{ng} \mathrm{m}^{-3}$ throughout the campaign. Note also those pPAHs concentrations in Mexico City have been reported by other groups using GC/MS and PAS (e.g., Villalobos-Pietrini et al., 2006; Saldarriaga et al., 2008; Murillo-Tovar et al., 2010; Villalobos-Pietrini et al., 2011; Amador-Muñoz et al., 2013; Ladino et al., 2018).

Given the health impacts of pPAHs and the lack of studies in cities other than Mexico City (a place with unique characteristics such as a high population, a vast amount of anthropogenic activities, and a large number of vehicles), it is necessary to carry out studies in mid-size Mexican towns with significant growth rates, to quantify the ambient pPAHs concentrations, identify their sources emission and evaluate, similarities/differences in diurnal patterns compared other pollutants. Moreover, studies should aim to understand the impact of pPAHs in the gradual deterioration of air quality, and in the health of the population, especially in the increase of respiratory and pulmonary illnesses (Dockery et al., 1993). Therefore, the present study aim to determine in situ pPAHs concentrations for the first time in Merida and to provide a scientific baseline to be used in policies for the reduction of emissions of pPAHs, pollutants with carcinogenic and mutagenic potential.

\section{METHODS}

\subsection{Sampling Site}

The data reported here were collected at the Merida atmospheric observatory, a sampling site of the University Network of Atmospheric Observatories (RUOA, Spanish acronym), supported by the National University of Mexico (UNAM). The sampling site is located in the central-western part of Merida within the School of Chemistry of the Autonomous University of Yucatan $\left(20.98^{\circ} \mathrm{N}\right.$, $89.64^{\circ} \mathrm{W}, 25 \mathrm{~m}$ a.s.I., Fig. 1). The School of Chemistry is approximately $35 \mathrm{~km}$ away from the Gulf of Mexico shore and $3 \mathrm{~km}$ away from the historic downtown. The site is surrounded by an industrial area $(6.5 \mathrm{~km})$, and it is mainly impacted by emissions from traffic by private vehicles, public transportation, and heavy-duty vehicles throughout the day. Climate is warm, with annual average temperature and relative humidity of $26^{\circ} \mathrm{C}$ and $79 \%$, respectively. While the minimum average temperature is $16^{\circ} \mathrm{C}$ in January, the warm season goes from April to August, reaching temperatures as high as $40^{\circ} \mathrm{C}$. Merida is located close to sea level and is influenced by humid marine airmasses (Rodriguez et al., 2020). The Köppen Climate classification subtype for this region is "Aw", corresponding to Tropical Savanna Climate. Tropical storms can impact the Yucatan Peninsula affecting Merida between August and October and, albeit infrequently, even in November. Also, the region is impacted every year by the arrival of cold fronts from November

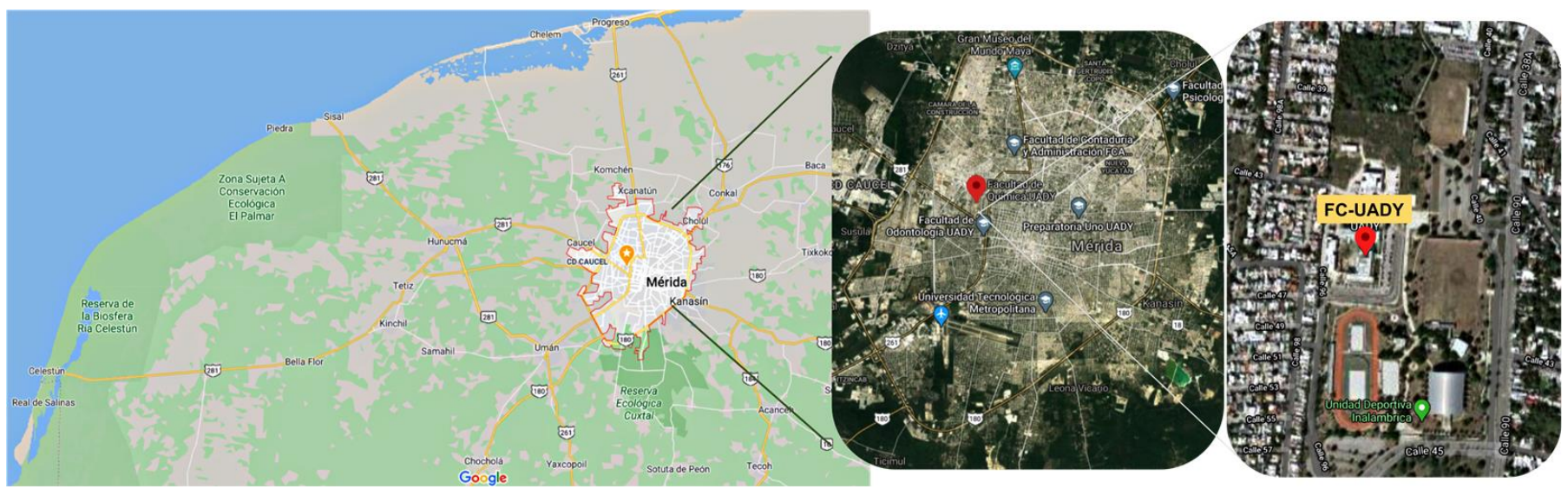

Fig. 1. Sampling site in Merida, Yucatan. FC-UADY refers to the School of Chemistry of the Autonomous University of Yucatan (Map source: Google Maps). 
to March (INEGI, 2018). Merida, the capital of the State of Yucatan, is a rapidly developing city with currently 892 363 inhabitants, in a state of 2097175 inhabitants with a 1.2\% annual growth rate (INEGI, 2017).

\section{2 pPAHs Measurements}

The concentration of pPAHs was measured with a portable sensor based on a photoelectric cell, known as Photoelectric Aerosol Sensor (PAS, Model 2000, Ecochem), which can measure pPAHs in the range of 0.01 and $5000 \mathrm{ng} \mathrm{m}^{-3}$ (Niessner, 1986; Marr et al., 2006). The PAS employs pulsed UV light $(222 \mathrm{~nm})$ to ionize the pPAHs, while gas molecules and other aerosol particles remain neutral. After ionization, each pPAHs emits electrons, which are subsequently removed in an electric field. The remaining positively charged particles are collected on a filter inside an electrometer, where the charge is measured. The resulting electric current is proportional to the concentration of pPAHs (https://ecochem.biz/Particles/PASDesktop. php). The ionization potentials of pPAHs surface are generally below the energy of the incident photons. However, the PAS is also sensitive to elemental carbon. Some other organic compounds can also be ionized (Matter et al., 1999; Baumgardner et al., 2007) and contribute to the PAS signal; hence, the PAS signal should be considered a relative, rather than absolute concentration resulting of the possible mixture of pPAHs, elemental carbon, and some trace amounts of other organics. The PAS manufacturer cautions that the instrument must be calibrated with the aerosol mixture being studied if the results are to be interpreted quantitatively. This type of calibration is difficult due to the urban environment where the aerosol mixture will change significantly depending on the relative fractions of elemental carbon and organic compounds (Baumgardner et al., 2007). The photoelectric aerosol sensors are useful for measuring pPAHs with $\geq$ four rings, compounds with a large $\pi$-electron system that are easily photoionized (Niessner 1986; Burtscher 1992; Wilson et al., 1994; Ramamurthi and Chuang 1997; Dunbar et al., 2001). One limitation of the Photoelectric Aerosol Sensor is that individual pPAH species cannot be distinguished. Another limitation is that the contribution of individual pPAH to the total photoemission signal may not be directly proportional to their concentration on the particles. Uncertainty in pPAHs mass concentrations is on the order of $20 \%$ (Marr et al., 2006; Ladino et al., 2018).

Despite these limitations, photoelectric aerosol sensors have been successfully used to measure pPAHs given their high time resolution, portability, and robustness. The pPAHs data reported in the present work were collected from 19 October 2017 to 20 March 2018 for a total of 132 non-consecutive days as part of the African Dust and Biomass Burning Over Yucatan project (ADABBOY). A cross-calibration was carried out with our PAS and a PAS factory-calibrated using a sampling candle soot and ambient air at concentrations of $20-3000 \mathrm{ng} \mathrm{m}^{-3}$ for 5-30 min on three separate occasions, as described in Marr et al. (2006). Additionally, both PAS reported a null concentration when a zero-air filter was applied. The PAS's time resolution is $1 \mathrm{~s}$, and the flow rate was set to $2 \mathrm{~L} \mathrm{~min}^{-1}$.

\subsection{Other Measurements}

The light absorption coefficient of aerosol particles was measured with a Particle Soot Absorption Photometer (PSAP). The PSAP measures the optical transmittance using a light-emitting diode at $550 \mathrm{~nm}$, through a quartz filter over time as particles are deposited. This means that the PSAP technique measures the particle absorption coefficient as a function of the decrease in transmittance as aerosol particles accumulate on the filter. Ambient air passes through two identical quartz filters that are in series. While the aerosol sample is collected on the exposed area $(\sim 0.5 \mathrm{~cm}$ in diameter) of the first filter (i.e., the sample filter), the second filter is used as reference. The reference filter is exposed to the same ambient air, but it is aerosol-free. Light is transmitted through the sample and reference filters and light intensities detected are compared between both to determine the absorption coefficient using Beer's-Law (Bond et al., 1999; Baumgardner et al., 2007).

Aerosol characteristics (particle size and concentration) were monitored with an optical particle counter (LASAIR II, Model 310A, Particle Measuring System). The LASAIR detects particle number concentrations in six size bins: $0.3,0.5,1.0,5.0,10.0$, and $25 \mu \mathrm{m}$ (Ladino et al., 2019).

The concentration of $\mathrm{NO}_{x}$ and $\mathrm{CO}$ were obtained from the RUOA station in Merida, with a 
chemiluminescence $\mathrm{NO}_{x}$ analyzer (Model 42I, Thermo-Fisher Scientific, USA) and a non-dispersive infrared analyzer (Model 48I, Thermo-Fisher Scientific, USA), respectively. The RUOA site also has a meteorological station to measure air temperature and relative humidity with a thermohygrometer (Vaisala HMP155A).

Finally, the hybrid single-particle lagrangian integrated trajectory (HYSPLIT) model from National Oceanic and Atmospheric Administration (NOAA) was used to evaluate the origin of the air masses arriving in Merida (https://ready.noaa.gov/HYSPLIT.php).

\section{RESULTS AND DISCUSSION}

\subsection{Average Diurnal and Weekly Cycles of pPAHs}

The pPAHs concentration obtained from 19 October 2017 to 20 March 2018 is shown in Fig. 2. Maximum average concentrations were observed in October $\left(21 \pm 17 \mathrm{ng} \mathrm{m}^{-3}\right)$, November $(19 \pm$ $\left.13 \mathrm{ng} \mathrm{m}^{-3}\right)$, and January $\left(20 \pm 17 \mathrm{ng} \mathrm{m}^{-3}\right)$, while the lowest average concentrations were found in February $\left(16 \pm 5 \mathrm{ng} \mathrm{m}^{-3}\right)$ and March $\left(16 \pm 5 \mathrm{ng} \mathrm{m}^{-3}\right)$ (Table S1). Due to technical issues with the PAS 2000, the pPAHs concentrations are not fully continuous (missing data between 27 November and 10 December 2017, and between 29 January and 04 February 2018). A more detailed inspection of the data suggests the presence of two different regimes in the variability of ambient concentrations based on the highest and lowest monthly pPAHs concentration: the first one (19 October-14 January) with an average of $20 \pm 16 \mathrm{ng} \mathrm{m}^{-3}$ and the second regime (15 January-20 March) with an average of $16 \pm 5 \mathrm{ng} \mathrm{m}^{-3}$. The small value in the second regime may be associated with the increase in the speed of the trade winds (Table S1).

Very large pPAHs concentrations were observed overnight on 24 November $\left(245 \pm 49 \mathrm{ng} \mathrm{m}^{-3}\right)$, 11 December $\left(196 \pm 39 \mathrm{ng} \mathrm{m}^{-3}\right)$, and 13 December $\left(207 \pm 41 \mathrm{ng} \mathrm{m}^{-3}\right)$. And were also elevated during the night on 17 November $\left(197 \pm 39 \mathrm{ng} \mathrm{m}^{-3}\right)$ and 22 November $\left(199 \pm 40 \mathrm{ng} \mathrm{m}^{-3}\right)$. These maximum concentration peaks will not be considered in this analysis section, as they are considered atypical data and will be analyzed separately in the next section.

The average concentration of pPAHs during the sampling period was $19 \pm 11 \mathrm{ng} \mathrm{m}^{-3}$, similar to the one reported for the southern sector of Mexico City between April and May 2003, i.e., $18 \mathrm{ng} \mathrm{m}^{-3}$ (Dzepina et al., 2007), and lower than the more recent measurements reported by Ladino et al. (2018) for April 2016 and March 2017 (i.e., $32 \mathrm{ng} \mathrm{m}^{-3}$ ). This difference is more

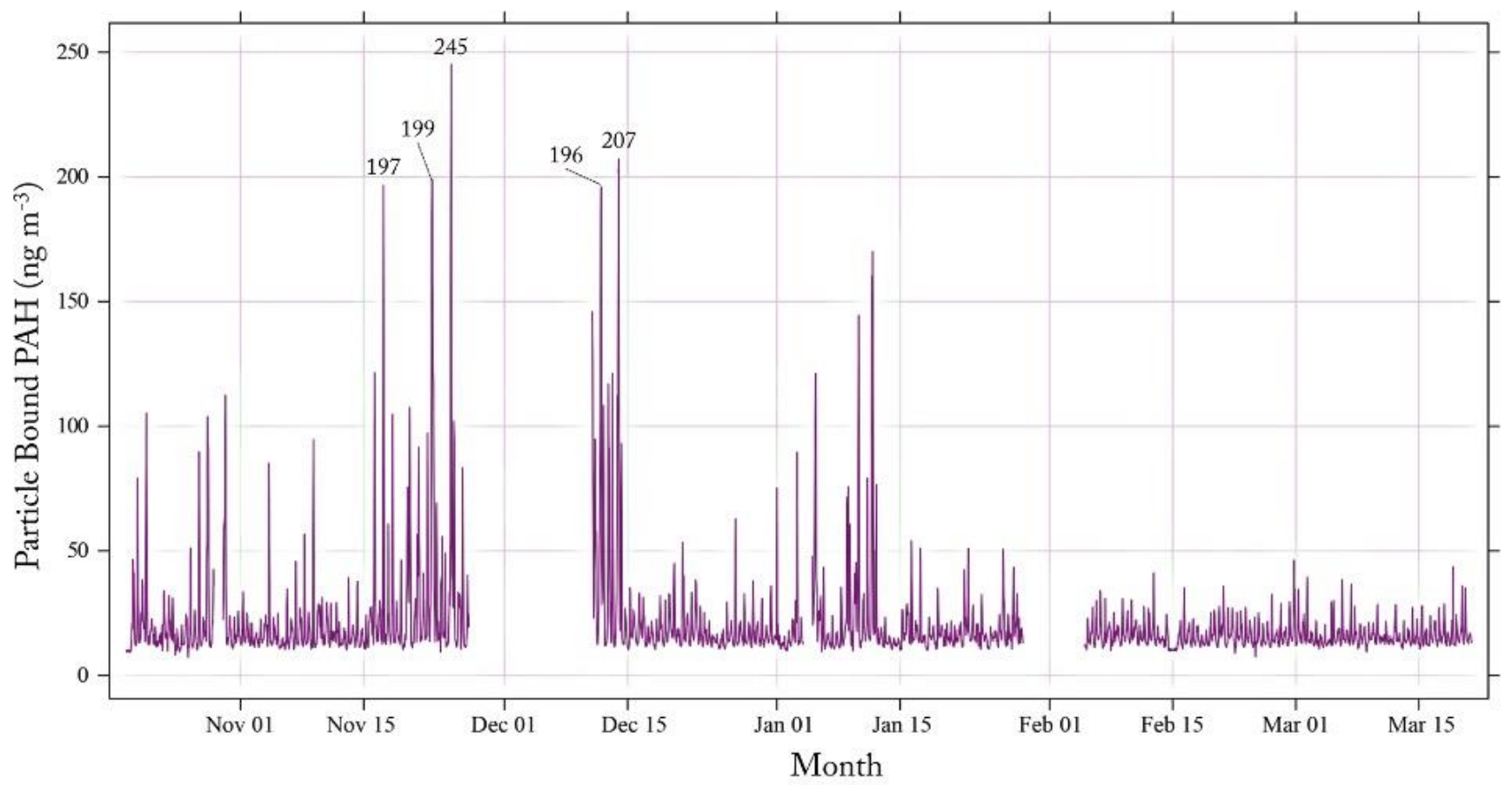

Fig. 2. Time series of pPAHs concentration in Merida for the entire sampling period. Peaks with values are atypical data. 
pronounced when compared with the values reported by Thornhill et al. (2008) for the northern sector of Mexico City (i.e., $50 \mathrm{ng} \mathrm{m}^{-3}$ ), where there is an industrial park with heavy-duty traffic (Ladino et al., 2018). However, when compared with other large cities around the world such as Boston (29 $\mathrm{ng} \mathrm{m}^{-3}$, Levy et al., 2001), Los Angeles (88.3 $\mathrm{ng} \mathrm{m}^{-3}$, Westerdahl et al., 2005) and Quito (220 $\mathrm{ng} \mathrm{m}^{-3}$, Brachtl et al., 2009), the pPAHs concentrations found in Merida are lower.

Average daily profiles help to identify the pPAHs sources. The results showed a bimodal behavior with two well defined peaks (Fig. 3); the first peak appears in the morning hours, between 05:00 and 11:00 with a maximum at 08:00 $\left(37 \pm 7 \mathrm{ng} \mathrm{m}^{-3}\right)$, and the second one around 20:00 hours $\left(23 \pm 5 \mathrm{ng} \mathrm{m}^{-3}\right)$. While the first peak is associated with vehicular emissions as a consequence of the start of routine activities, the second peak is likely related to the evening commute. The difference between the two peaks could be attributed to the lengths and variability of the daily activities. Additionally, as Fig. 3 shows, the pPAHs detection by the PAS 2000 seems to be heat sensitive. Fig. S1 (supplementary information) shows the inverse correlation between temperature and pPAHs concentrations during the day (Pearson's correlation coefficient, $r=-0.78$ ). This was previously shown by other studies where dilution due to the increasing boundary layer height, partitioning from particle-to-gas phase of volatile pPAHs, and coating of pPAHs with secondary organic aerosol, are all potential explanations for the low pPAHs concentrations in the afternoon (Dimashki et al., 2001; Marr et al., 2006; Ladino et al., 2018). Note that this inverse correlation between the concentration of pPAHs and temperature is also evident on a monthly or seasonal basis (Figs. 2 and S2).

The weekly cycle of pPAHs concentration shows that the concentrations remain almost constant; however, on Sunday, there is a noticeable decrease associated with a reduction in the number of private vehicles, public transport, and heavy traffic (Fig. 4). This reinforces the correlation between the burning of fossil fuels and pPAHs levels, which has been widely documented elsewhere (e.g., Dunbar et al., 2001; Westerdahl et al., 2005; Marr et al., 2006; Dzepina et al., 2007; Ladino et al., 2018).

Give that pPAHs are co-emitted with $\mathrm{CO}$ and $\mathrm{NO}_{\mathrm{x}}$ as a result of the incomplete combustion of fossil fuels used by public and private vehicles (Wang et al., 2019), the relationship between pPAHs and both gases were evaluated. Fig. 5(a) shows a similar behavior between the average daily profile of $\mathrm{CO}$ and pPAHs concentrations, indicative of common emission sources. This good relationship between both pollutants is confirmed by the Pearson's correlation coefficient obtained from the linear regression shown in Fig. 5(b) ( $r=0.80)$. A similar behavior was observed between pPAHs and $\mathrm{NO}_{x}$ (Fig. 5(c)) with a Pearson's correlation coefficient of 0.81 (Fig. 5(d)). Therefore, it is possible to infer that the main source of pPAHs in Merida is the incomplete combustion of fossil fuels, in agreement with studies conducted in other sites (e.g., Dunbar et al., 2001; Westerdahl et al., 2005; Marr et al., 2006; Dzepina et al., 2007; Ladino et al., 2018; Wang et al., 2019).

Another co-emitted pollutant from the incomplete combustion of fossil fuels is black carbon particles. The absorption coefficient $\left(B_{a b s}\right)$ of ambient particles was measured in parallel to the

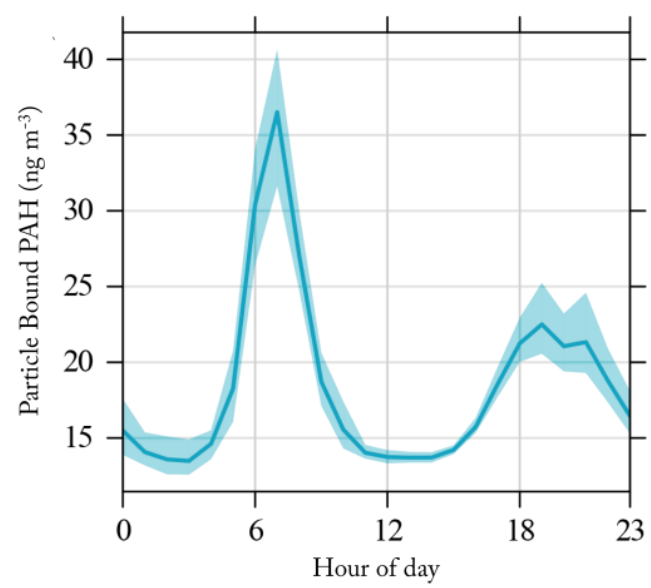

Fig. 3. Average daily profile of pPAHs in Merida for the entire sampling period. The shading highlights the standard deviation. 


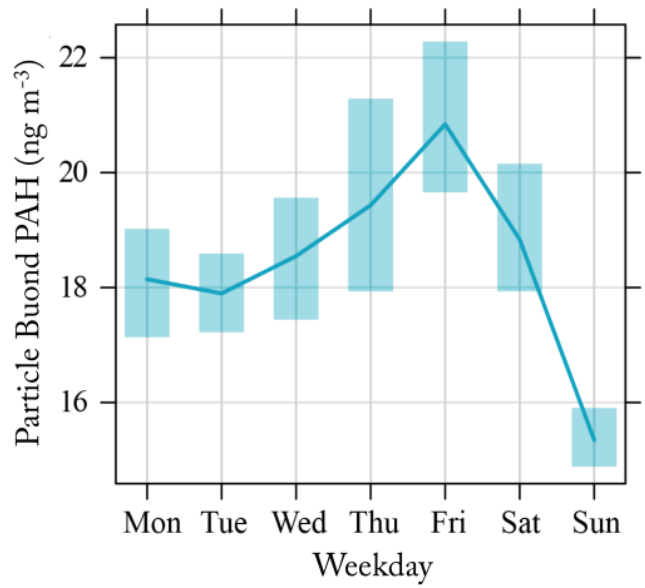

Fig. 4. Average weekly variation of pPAHs in Merida for the entire sampling period.
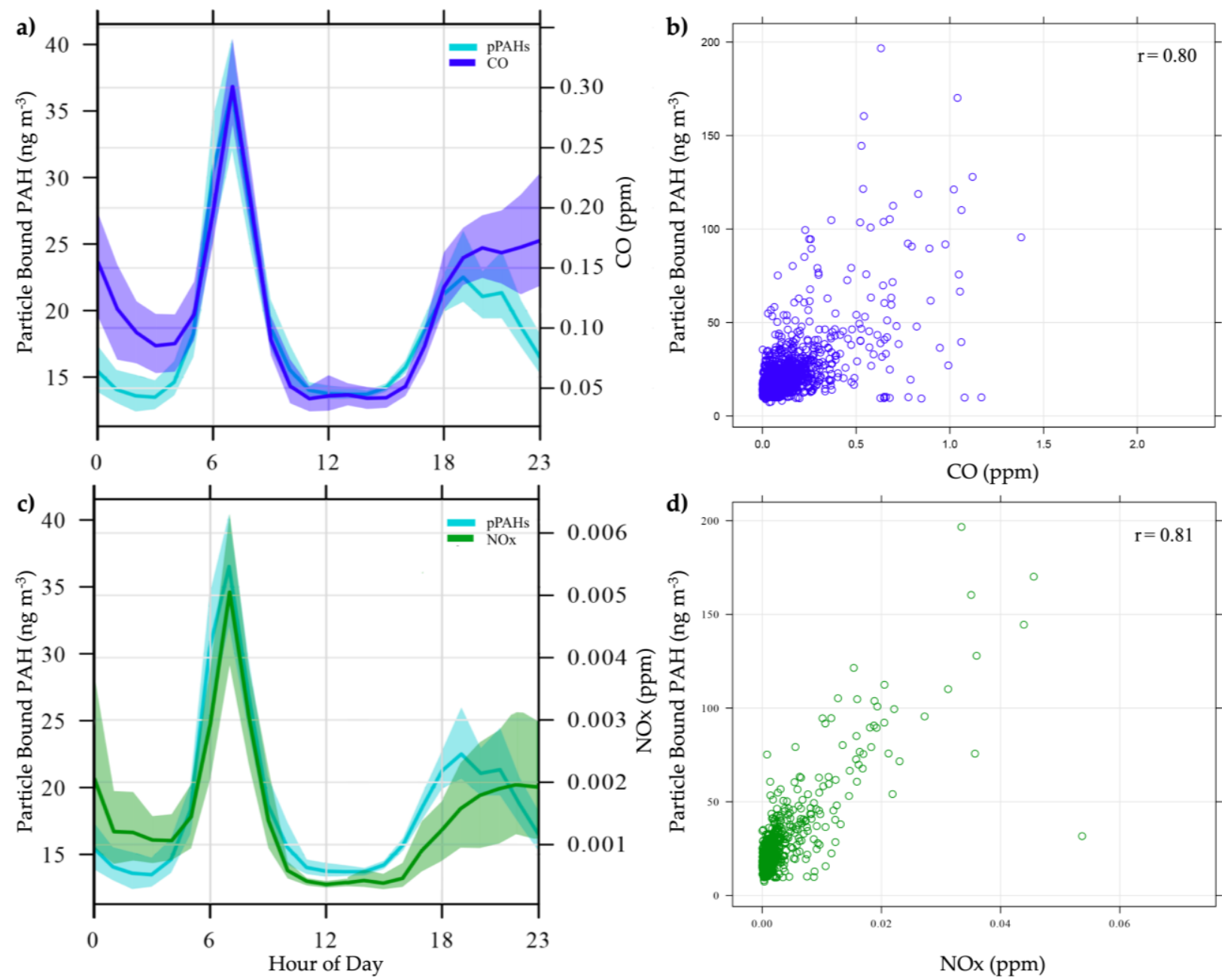

Fig. 5. (a) Average daily profile of the $\mathrm{CO}$ and pPAHs concentrations for the entire sampling period, (b) $\mathrm{CO}$ and pPAHs correlations, (c) Average daily profile of the $\mathrm{NO}_{x}$ and pPAHs concentrations for entire sampling period, and d) $\mathrm{NO}_{x}$ and pPAHs correlations.

pPAHs concentrations to estimate the BC concentration. Fig. 6 shows that the pPAHs concentration and $B_{a b s}$ daily profiles are in great agreement, with a resulting Pearson's correlation coefficient of 0.80 . Overall, the good correlation of $B_{a b s}, \mathrm{NO}_{\mathrm{x}}$, and $\mathrm{CO}$ with pPAHs supports the conclusion that the main pPAHs source is emissions from local vehicles. 

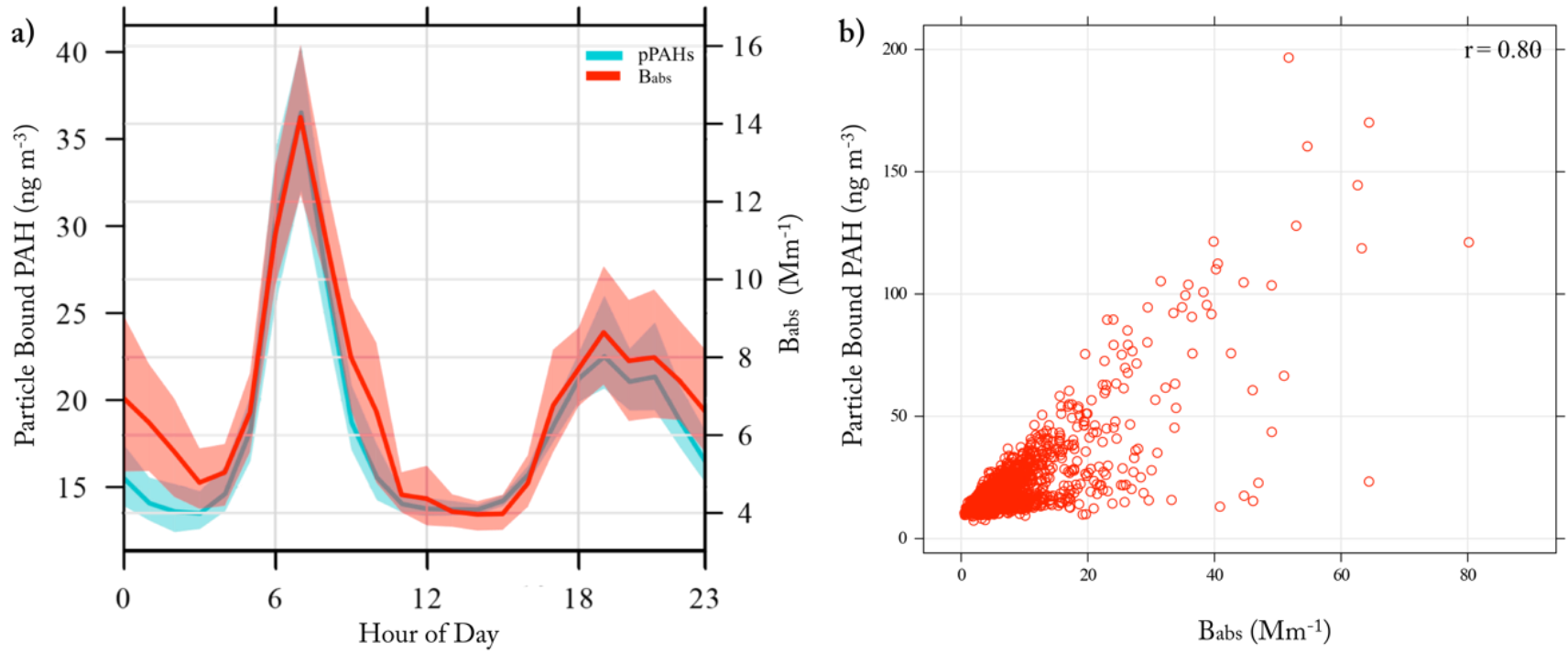

Fig. 6. (a) Average daily profile of the absorption coefficient $\left(B_{a b s}\right)$ and pPAHs concentrations for the entire sampling period, and (b) absorption coefficient $\left(B_{a b s}\right)$ and pPAHs correlations.

\subsection{Diurnal Cycle of Anomalous pPAHs Concentrations}

Fig. 2 indicates the occurrence of several days with extremely high pPAHs concentrations with values above $170 \mathrm{ng} \mathrm{m}^{-3}$. Those peaks do not represent an artifact from the PAS 2000, as they correlate $(r>0.8)$ with the time series of $\mathrm{CO}, \mathrm{NO}_{x}$, and $B_{a b s}$ as shown in Figs. S3 and S4. Therefore, those peaks were labeled as "atypical" and analyzed separately and not included in the average concentrations presented in the previous section.

Fig. 7 shows the composite, average daily cycle of pPAHs, including only atypical data (not necessarily consecutive days). This composite shows much higher concentrations than the average cycle shown in Fig. 3. Note that only the overnight peak shows a much higher concentration than the average of the overnight peak for "normal" days, but also that the variability is much larger on these atypical days. At midnight the pPAHs concentration is higher than at noon, with values above $100 \mathrm{ng} \mathrm{m}^{-3}$. Note that during normal days the average pPAHs concentration at midnight is $23 \mathrm{ng} \mathrm{m}^{-3}$. This atypical behavior suggests that during those days there is an additional source of pPAHs as most of the private and, even public vehicles, are not circulating at that time of the day. Some of the potential additional sources include industrial activities and burning of biomass, coal and/or solid waste. HYSPLIT back trajectories were run to determine if the air masses that arrived at the sampling site during those days were carrying pPAHs from local sources or transported from long distances into Merida.

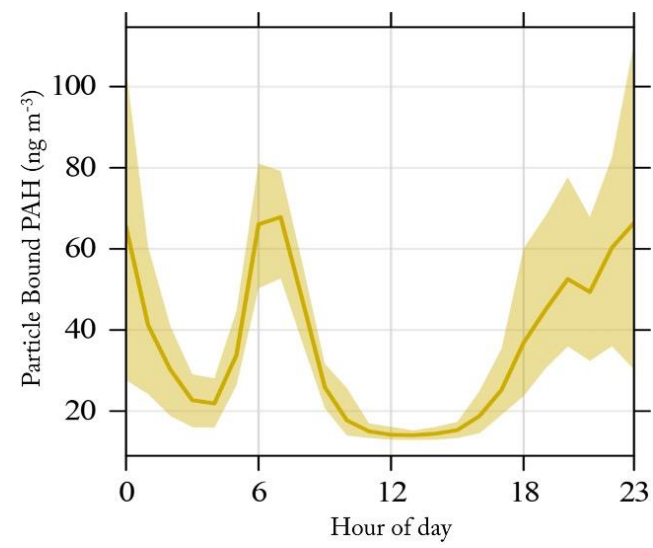

Fig. 7. Average daily profile of pPAHs during atypical days (i.e., 17, 22 and 24 November; 11 and 13 December 2017). 
Table 1. Pearson's correlation coefficient between pPAHs concentration with $\mathrm{PM}_{1}$, and $\mathrm{PM}_{5}$ during atypical days. Bold indicates significance at $95 \%$ level.

\begin{tabular}{lll}
\hline Date & $\mathrm{PM}_{1}$ & $\mathrm{PM}_{5}$ \\
\hline 21 Nov 2017 & 0.67 & -0.43 \\
22 Nov 2017* & 0.90 & 0.01 \\
23, Nov 2017 & 0.46 & 0.58 \\
11 Dec 2017* & 0.68 & 0.45 \\
12 Dec 2017 & 0.79 & 0.46 \\
13 Dec 2017* & 0.90 & 0.72 \\
14 Dec 2017 & 0.62 & 0.49 \\
\hline
\end{tabular}

*Atypical day.

The HYSPLIT results indicate that the trajectories followed by the air masses are similar for 22 November ("atypical" day), 23 November ("normal" day) and 24 November ("atypical" day) as shown in Figs. S5-S7. Therefore, this suggests that unless there are additional sources active during these days along the same airmass trajectories, pPAHs concentrations should be within the same range of values as during "normal" days. A similar behavior was found for the atypical days in December 2017 as shown in Figs. S8-S10. Based on the back trajectories, it is possible to qualitatively conclude that the high pPAHs values found at midnight are likely caused by a local source that is only sporadically active. To confirm the previous assumption, a correlation between pPAHs concentration with particles smaller than $1 \mu \mathrm{m}$ ( $\mathrm{PM}_{1}$, fresh particles) and with $5 \mu \mathrm{m}$ ( $\mathrm{PM}_{5}$, aged particles) obtained from the LASAIR II, was performed as shown in Table 1.

The correlation analysis between pPAHs concentration, $\mathrm{PM}_{1}$, and $\mathrm{PM}_{5}$ for 22 November and 11 and 13 December shows a strong relationship with $\mathrm{PM}_{1}$ particles with $r>0.7$. Note that for 24 November the correlation could not be performed due to missing data from the optical particle counter. This high correlation with $\mathrm{PM}_{1}$ suggests that the pPAHs from the atypical peaks were emitted rather close to the sampling site. Thus, the pPAHs were likely emitted from a local source, not vehicular traffic, but possibly open-air burning (Aurela et al., 2016). One possibility would be biomass burning associated with agricultural activities, that occurs every year between January and May in the Yucatan Peninsula, including in and around Merida (Rios and Raga, 2018). Another possible source could be the burning of municipal solid waste, a common activity in Yucatan. The State Government acknowledges this source and its risks and has designated a committee for the prevention and extinction of fires, which has among its powers is to carry out actions to prevent fires in municipal landfills and garbage dumps (http://sds.yucatan.gob.mx/consejos-comites/ince ndios.php). However, in the period in which the atypical data were presented, there were no reports of biomass burning associated with agriculture nor fires in municipal garbage dumps. Therefore, the atypical peaks are likely associated with the burning of residential or neighborhood-scale solid waste, a common illegal activity in Yucatan, which is generally carried out at night to avoid fines by authorities (https://www.theyucatantimes.com/2018/01/air-quality-tobe-monitored-in-downtown-merida/). In fact, according to the emissions inventory for Yucatan presented in the Management Program to Improve Air Quality 2016 (PROAIRE-Yucatan 20182027), solid waste burning (anthropogenic source) emits $1005 \mathrm{Mg}$ of $\mathrm{PM}_{10}, 921 \mathrm{Mg}$ of $\mathrm{PM}_{2.5}, 2248$ $\mathrm{Mg}$ of $\mathrm{CO}, 159 \mathrm{Mg}$ of $\mathrm{NO}_{\mathrm{x}}$ and $226 \mathrm{Mg}$ of volatile organic compounds per year. However, to confirm this association, it is necessary to carry out a chemical speciation to identify important compounds such as polychlorinated dibenzodioxins, polychlorinated benzenes, polychlorinated biphenyls, polychlorinated phenols, polychlorinated diphenyl ethers, polychlorinated dibenzofurans, polybrominated diphenyl ethers, polybrominated dibenzo- $p$-dioxins, and furans (Rahman et al., 2001; Weber and Kuch, 2003; Sidhu et al., 2005; Nakao et al., 2006; Gullett et al., 2010; Solorzano-Ochoa et al., 2012).

\section{CONCLUSIONS}

Particle-bound PAHs are organic compounds with proven genotoxic, carcinogenic and mutagenic properties produced during combustion and industrial processes that may lead to 
serious public health and environmental problems. The continuous monitoring reported in this study allows us to evaluate important emission sources which could aid in the establishment of air quality standards in a mid-size, but rapidly growing city.

This study carried out from October 2017 to March 2018, revealed large diurnal variability in the concentration of pPAHs in Merida. Furthermore, pPAHs concentration exhibits an inverse relationship with air temperatures. This was the case for February (16 $\left.\pm 5 \mathrm{ng} \mathrm{m}^{-3}\right)$ and March (16 $\pm 5 \mathrm{ng} \mathrm{m}^{-3}$ ), two months with the lowest pPAHs concentrations and the highest temperatures. In contrast, October and November reported the highest pPAHs concentration, with average values of $21 \pm 17$ and $19 \pm 13 \mathrm{ng} \mathrm{m}^{-3}$, respectively. A bimodal distribution of the pPAHs concentration was observed in the daily cycles, with peak concentrations at 08:00 (37 $\left.\pm 7 \mathrm{ng} \mathrm{m}^{-3}\right)$ and 20:00 $\mathrm{hrs}$ $\left(23 \pm 5 \mathrm{ng} \mathrm{m}^{-3}\right)$, local time. Both peaks are clearly associated with emissions from the incomplete combustion of fossil fuels by vehicles. These emissions contain benzo[a]pyrene, a compound representing ca $7 \%$ and $2 \%$ of pPAHs in gasoline and diesel exhaust, respectively (Marr et al., 2004). Additionally, the source emission was confirmed by evaluating the correlation coefficient between pPAHs, $\mathrm{CO}, \mathrm{NO}_{x}$, and the absorption coefficient of the sampled airborne particles.

Several atypical cases in the diurnal cycle were present throughout several weeks during the sampling period. The atypical nocturnal values identified in this study could be the result of burning of solid waste, a practice that still takes place in many peri-urban regions (e.g., even around Mexico City) and, most likely also in Merida. This was evident on 22 and 24 November, and 11 and 13 December, when extremely high pPAHs concentrations were observed late in the evening. Given that pPAHs showed a good correlation with $\mathrm{PM}_{1}$, we infer that those are fresh particles originated from local sources such as residential waste burning.

The average pPAHs concentration obtained in this study (i.e., $19 \pm 11 \mathrm{ng} \mathrm{m}^{-3}$ ) is lower than values found in two sites in Mexico City using the same method, as expected. The measurements obtained in this study provide a baseline for future estimates, given the current growth rate that Merida is experiencing. Although the concentration is low compared to other sites, the presence of benzo[a]pyrene as a component of pPAHs represents a health risk, according to the World Health Organization, which suggests a lifetime risk estimate ( $24 \mathrm{~h}$ per day over 70 years) for humans of $9 \times 10^{-2}$ per $\mathrm{ng} \mathrm{m}^{-3}$ (WHO, 2000). Therefore, local authorities need to strengthen their efforts to prevent or reduce these activities.

\section{ACKNOWLEDGEMENTS}

This study was financially supported by the Consejo Nacional de Ciencia y Tecnologia (CONACYT) through the FC-2164 grant. The authors thank the University Network of Atmospheric Observatories (RUOA) for providing meteorological and criteria pollution data. Also, we express our gratitude to Elizabeth Garcia, Darrel Baumgardner, and Talib Amador for their invaluable help and support.

\section{SUPPLEMENTARY MATERIAL}

Supplementary data associated with this article can be found in the online version at https://doi.org/10.4209/aaqr.200245

\section{REFERENCES}

Abdel-Shafy, H.I., Mansour, M.S.M. (2016). A review on polycyclic aromatic hydrocarbons: Source, environmental impact, effect on human health and remediation. Egypt. J. Pet. 25, 107123. https://doi.org/10.1016/j.ejpe.2015.03.011

Amador-Muñoz, O., Bazán-Torija, S., Villa-Ferreira, S.A., Villalobos-Pietrini, R., Bravo-Cabrera, J.L., Munive-Colín, Z., Hernández-Mena, L., Saldarriaga-Noreña, H., and Murillo-Tovar, M.A. (2013). Opposing seasonal trends for polycyclic aromatic hydrocarbons and $\mathrm{PM}_{10}$ : Health risk and sources in southwest Mexico City. Atmos. Res. 122, 199-212. https://doi.org/10.1016/j.atmo sres.2012.10.003 
Amagai, T., Takahashi, Y., Matsushita, H., Morknoy, D., Sukasem, P., Tabucanon, M. (1999). A survey on polycyclic aromatic hydrocarbon concentrations in soil in Chiang-Mai, Thailand. Environ. Int. 25, 563-572. https://doi.org/10.1016/S0160-4120(99)00026-4

Aurela, M., Beukes, J.P., Zyl, P., Vakkari, V., Teinila, K., Saarikoski, S., Laakso, L. (2016). The composition of ambient and fresh biomass burning aerosols. S. Afr. J. Sci. 11, 1-8. https://doi.org/10.17159/sajs.2016/20150223

Baek, S.O., Goldstone, M.E., Kirk, P.W.W., Lester, J.N., Perry, R. (1991). Phase distribution and particle size dependency of polycyclic aromatic hydrocarbons in the urban atmosphere. Chemosphere 22, 503-520. https://doi.org/10.1016/0045-6535(91)90062-I

Baumgardner, D., Kok, G.L., Raga, G.B. (2007). On the diurnal variability of particle properties related to light absorbing carbon in Mexico City. Atmos. Chem. Phys. 7, 2517-2526. https://doi.org/10.5194/acp-7-2517-2007

Bond, T., Anderson, T., Campbell, D. (1999). Calibration and intercomparison of filter-based measurements of visible light absorption by aerosols. Aerosol Sci. Technol. 30, 582-600. https://doi.org/10.1080/027868299304435

Brachtl, M.V., Durant, J.L., Perez, C.P., Oviedo, J., Sempertegui, F., Naumova, E.N., Griffiths, J.K. (2009). Spatial and temporal variations and mobile source emissions of polycyclic aromatic hydrocarbons in Quito, Ecuador. Environ. Pollut. 157, 528-36. https://doi.org/10.1016/j.envpo I.2008.09.041

Burtscher, H. (1992). Measurement and characteristics of combustion aerosols with special consideration of photoelectric charging and charging by flame ions. J. Aerosol Sci. 23, 549-595. https://doi.org/10.1016/0021-8502(92)90026-R

Choi, S.D., Kwon, H.O., Lee, Y.S., Park, E.J., Oh, J.Y. (2012). Improving the spatial resolution of atmospheric polycyclic aromatic hydrocarbons using passive air samplers in a multi-industrial city. J. Hazard. Mater. 241-242, 252-258. https://doi.org/10.1016/j.jhazmat.2012.09.039

Choi, S.D. (2014). Time trends in the levels and patterns of polycyclic aromatic hydrocarbons (PAHs) in pine bark, litter, and soil after a forest fire. Sci. Total Environ. 470-471, 1441-1449. https://doi.org/10.1016/j.scitotenv.2013.07.100

Delfino, R.J., Chang, J., Wu, J., Ren, C., Tjoa, T., Nickerson, B., Cooper, D., Gillen, D.L. (2009). Repeated hospital encounters for asthma in children and exposure to traffic-related air pollution near the home. Ann. Allergy Asthma Immunol. 102, 138-144. https://doi.org/10.101 6/S1081-1206(10)60244-X

Dimashki, M., Lim, L.H., Harrison, R.M., Harrad, S. (2001). Temporal trends, temperature dependence, and relative reactivity of atmospheric polycyclic aromatic hydrocarbons. Environ. Sci. Technol. 35: 2264-2267. https://doi.org/10.1021/es000232y

Dockery, D., Pope, C.A., Xu, X., Spengler, J., Ware, J., Fay, M., Ferris, B., Speizer, F. (1993). An association between air pollution and mortality in six U.S. cities. New England. J. Med. 329, 1753-1759. https://doi.org/10.1056/NEJM199312093292401

Dunbar, J.C., Lin, C.I., Vergucht, I., Wong, J., Durant, J.L. (2001). Estimating the contributions of mobile sources of PAH to urban air using real-time PAH monitoring. Sci. Total Environ. 279, 119. https://doi.org/10.1016/S0048-9697(01)00686-6

Dzepina, K., Arey, J., Marr, L.C., Worsnop, D.R., Salcedo, D., Zhang, Q., Onasch, T.B., Molina, L.T., Molina, M.J., Jimenez, J.L. (2007). Detection of particle-phase polycyclic aromatic hydrocarbons in Mexico City using an aerosol mass spectrometer. Int. J. Mass Spectrom. 263, 152-170. https://doi.org/10.1016/j.ijms.2007.01.010

Garcia-Suastegui, W., Huerta-Chagoya, A., Carrasco-Colin, K., Pratt, M., John, K., Petrosyan, P., Rubio, J., Poirier, M., Gonsebatt, M. (2011). Seasonal variations in the levels of PAH-DNA adducts in young adults living in Mexico City. Mutagenesis 26, 385-391. https://doi.org/10.109 3/mutage/geq104

Grosjean, D. (1983). Polycyclic aromatic hydrocarbons in Los Angeles air from samples collected on teflon, glass and quartz filters. Atmos Environ. 7, 2565-2573. https://doi.org/10.1016/00046981(83)90084-7

Gullett, B.K., Wyrzykowska, B., Grandesso, E., Touati, A., Tabor, D.G., Ochoa, G.S. (2010). PCDD/F, $\mathrm{PBDD} / \mathrm{F}$, and PBDE emissions from open burning of a residential waste dump. Environ. Sci. Technol. 44, 394-399. https://doi.org/10.1021/es902676w

INEGI (2017). Anuario estadístico y geográfico de Yucatán 2017. Avenida Héroes de Nacozari Sur 
2301, fraccionamiento Jardines del Parque , 20276 Aguascalientes, Aguascalientes.

INEGI (2018). México en cifras: Yucatán. 2018. https://www.inegi.org.mx/app/areasgeogra ficas/?ag=31

Jamhari, A.A., Sahani, M., Latif, M.T., Chan, K.M., Tan, H.S., Khan, M.F., Tahir, N.M. (2014). Concentration and source identification of polycyclic aromatic hydrocarbons (PAHs) in $\mathrm{PM}_{10}$ of urban, industrial and semi-urban areas in Malaysia. Atmos. Environ. 86, 16-27. https://doi.org/10.1016/j.atmosenv.2013.12.019

John, K., Ragavan, N., Pratt, M.M., Singh, P.B., Al-Buheissi, S., Matanhelia, S.S., Phillips, D.H., Poirier, M.C., Martin, F.L. (2009). Quantification of phase I/II metabolizing enzyme gene expression and polycyclic aromatic hydrocarbon-DNA adduct levels in human prostate. Prostate 69, 505-519. https://doi.org/10.1002/pros.20898

Kim, E.J., Choi, S.D., Chang, Y.S. (2011). Levels and patterns of polycyclic aromatic hydrocarbons (PAHs) in soils after forest fires in South Korea. Environ. Sci. Pollut. Res. 18, 1508-1517. https://doi.org/10.1007/s11356-011-0515-3

Kong, S., Ding, X., Bai, Z., Han, B., Chen, L., Shi, J., Li, Z. (2010). A seasonal study of polycyclic aromatic hydrocarbons in $\mathrm{PM}_{2.5}$ and $\mathrm{PM}_{2.5-10}$ in five typical cities of Liaoning Province, China. J. Hazard. Mater. 183: 70-80. https://doi.org/10.1016/j.jhazmat.2010.06.107

Kuo, C.Y., Cheng, Y.W., Chen, Y.W., Lee, H. (1998). Correlation between the amounts of polycyclic aromatic hydrocarbons and mutagenicity of airborne particulate samples from Taichung City, Taiwan. Environ. Res. 78, 43-49. https://doi.org/10.1006/enrs.1998.3838

Ladino, L., Raga, G., Baumgardner, D. (2018). On particle-bound polycyclic aromatic hydrocarbons $(\mathrm{PAH})$ and links to gaseous emissions in Mexico City. Atmos. Environ. 194, 31-40. https://doi.org/10.1016/j.atmosenv.2018.09.022

Ladino, L.A., Raga, G.B., Alvarez-Ospina, H., Andino-Enríquez, M.A., Rosas, I., Martínez, L., Salinas, E., Miranda, J., Ramírez-Díaz, Z., Figueroa, B., Chou, C., Bertram, A.K., Quintana, E.T., Maldonado, L.A., García-Reynoso, A., Si, M., Irish, V.E. (2019). Ice-nucleating particles in a coastal tropical site. Atmos. Chem. Phys. 19, 6147-6165. https://doi.org/10.5194/acp-196147-2019

Levy, J.I., Houseman, E.A., Spengler, J.D., Loh, P., Ryan, L. (2001). Fine particulate matter and polycyclic aromatic hydrocarbon concentration patterns in Roxbury, Massachusetts: A community-based GIS analysis. Environ. Health Perspect. 109, 341-347. https://doi.org/10.12 89/ehp.01109341

Maliszewska-Kordybach, B. (1999). Sources, concentrations, fate and effects of polycyclic aromatic hydrocarbons (PAHs) in the environment. Part A: PAHs in air. Pol. J. Environ. Stud. 8: 131-136.

Marr, L.C., Dzepina, K., Jimenez, J.L., Reisen, F., Bethel, H.L., Arey, J., Gaffney, J.S., Marley, N.A., Molina, L.T., Molina, M.J. (2006). Sources and transformations of particle-bound polycyclic aromatic hydrocarbons in Mexico City. Atmos. Chem. Phys. 6, 1733-1745. https://doi.org/10.5 194/acp-6-1733-2006

Marr, L.C., Grogan, L.A., Wohrnschimmel, H., Molina, L.T., Molina, M.J., Smith, T.J., Garshick, E. (2004). Vehicle traffic as a source of particulate polycyclic aromatic hydrocarbon exposure in the Mexico City Metropolitan Area. Environ. Sci. Technol. 38, 2584-2592. https://doi.org/10.1 021/es034962s

Matter, U., Siegmann, H.C., Burtscher, H. (1999). Dynamic field measurements of submicron particles from diesel engines. Environ. Sci. Technol. 33, 1946-1952. https://doi.org/10.1021/es 981095w

Menzie, C.A., Potocki, B.B., Santodonato, J. (1992). Exposure to carcinogenic PAHs in the environment. Environ. Sci. Technol. 26, 1278-1284. https://doi.org/10.1021/es00031a002

Murillo-Tovar, M., Amador-Muñoz, O., Villalobos-Pietrini, R., Marriott, P.J. (2010). Selective separation of oxy-PAH from n-alkanes and PAH in complex organic mixtures extracted from airborne $\mathrm{PM}_{2.5}$. Chromatographia 72, 913-921. https://doi.org/10.1365/s10337-010-1738-z

Nakao, T., Aozasa, O., Ohta, S., Miyata, H. (2006). Formation of toxic chemicals including dioxinrelated compounds by combustion from a small home waste incinerator. Chemosphere 62, 459-468. https://doi.org/10.1016/j.chemosphere.2005.04.060

Nguyen, T.N.T., Jung, K.S., Son, J.M., Kwon, H.O., Choi, S.D. (2018). Seasonal variation, phase distribution, and source identification of atmospheric polycyclic aromatic hydrocarbons at a 
semi-rural site in Ulsan, South Korea. Environ. Pollut. 236, 529-539. https://doi.org/10.1016/j. envpol.2018.01.080

Niessner, R. (1986). The chemical response of the photo-electric aerosol sensor (PAS) to different aerosol systems. J. Aerosol Sci. 17, 705-714. https://doi.org/10.1016/0021-8502(86)90050-9

Nisbet, I.C., LaGoy, P.K. (1992). Toxic equivalency factors (TEFs) for polycyclic aromatic hydrocarbons (PAHs). Regul. Toxicol. Pharmacol. 16: 290-300. https://doi.org/10.1016/02732300(92)90009-X

Ohura, T., Amagai, T., Fusaya, M., Matsushita, H. (2004). Spatial distributions and profiles of atmospheric polycyclic aromatic hydrocarbons in two industrial cities in Japan. Environ. Sci. Technol. 38, 49-55. https://doi.org/10.1021/es030541z

Phan, Q.T., Seong-Joon, K., Sang-Jin, L., Jin, Y., Young-Kyo, S., Sung-Ok, B., Sung-Deuk, C. (2019). Seasonal characteristics of particulate polycyclic aromatic hydrocarbons (PAHs) in a petrochemical and oil refinery industrial area on the west coast of South Korea. Atmos. Environ. 198, 398-406. https://doi.org/10.1016/j.atmosenv.2018.11.008

Pongpiachan, S., Hattayanone, M., Choochuay, C., Mekmok, R., Wuttijak, N., Ketratanakul, A. (2015). Enhanced $\mathrm{PM}_{10}$ bounded PAHs from shipping emissions. Atmos. Environ. 108, 13-19. https://doi.org/10.1016/j.atmosenv.2015.02.072

Pongpiachan, S., Hattayanone, M., Suttinun, O., Khumsup, C., Kittikoon, I., Hirunyatrakul, P., Cao, J. (2017), Assessing human exposure to $\mathrm{PM}_{10}$-bound polycyclic aromatic hydrocarbons during fireworks displays. Atmos. Pollut. Res. 8, 816-827. https://doi.org/10.1016/j.apr.2017.01.014

Rahman, F., Langford, K.H., Scrimshaw, M.D., Lester, J.N. (2001). Polybrominated diphenyl ether (PBDE) flame retardants. Sci. Total Environ. 275, 1-17. https://doi.org/10.1016/S00489697(01)00852-X

Ramamurthi, M., Chuang, J.C. (1997). Field and laboratory evaluations of a real-time PAH analyzer, EPA/600/R-97/034, US Environmental Protection Agency, National Exposure Research Laboratory, Research Triangle Park, NC.

Ravindra, K., Sokhi, R., Van Grieken, R. (2008). Atmospheric polycyclic aromatic hydrocarbons: Source attribution, emission factors and regulation. Atmos. Environ. 42, 2895-2921. https://doi.org/10.1016/j.atmosenv.2007.12.010

Rios, B., Raga, G.B. (2018). Smoke emissions from agricultural fires in Mexico and Central America. J. Appl. Remote Sens. 13, 036509. https://doi.org/10.1117/1.JRS.13.036509

Rodriguez-Gomez, C., Ramirez-Romero, C., Cordoba, F., Raga, G., Salinas, E., Martinez, L., Rosas, I., Quintana, E., Maldonado, L., Rosas, D., Amador, T., Alvarez, H., Ladino, L. (2020). Characterization of culturable airborne microorganisms in the Yucatan Peninsula. Atmos. Environ. 223, 117183. https://doi.org/10.1016/j.atmosenv.2019.117183

Salazar, S., Diaz-Gonzalez, G., Botello, A.V. (1991). Presence of aliphatic and polycyclic aromatic hydrocarbons in the atmosphere of northwestern Mexico City, Mexico. Bull. Environ. Contam. Toxicol. 46, 690-696. https://doi.org/10.1007/BF01689954

Saldarriaga, H., Villalobos, R., Solano, G., Amador, O., Gaspariano, R., Palma, R., Munive, Z. (2008). Aliphatic, polycyclic aromatic hydrocarbons in $\mathrm{PM}_{10}$ in Southwestern Mexico City. Polycycl. Aromat. Comp. 28, 578-597. https://doi.org/10.1080/10406630802373822

Sarigiannis, D., Karakitsios, S.P., Zikopoulos, D., Nikolaki, S., Kermenidou, M. (2015). Lung cancer risk from PAHs emitted from biomass combustion. Environ. Res. 137, 147-156. https://doi.org/10. 1016/j.envres.2014.12.009

Sidhu, S., Gullett, B., Striebich, R., Klosterman, J., Contreras, J., DeVito, M. (2005). Endocrine disrupting chemical emissions from combustion sources: diesel particulate emissions and domestic waste open burn emissions. Atmos. Environ. 39, 801-811. https://doi.org/10.1016/j. atmosenv.2004.10.040

Solorzano-Ochoa, G., de la Rosa, D.A., Maiz-Larralde, P., Gullett, B.K., Tabor, D.G., Touati, A., Wyrzykowska-Ceradini, B., Fiedler, H., Abel, T., Carroll, Jr. W.F. (2012). Open burning of household waste: Effect of experimental condition on combustion quality and emission of PCDD, PCDF and PCB. Chemosphere 87, 1003-1008. https://doi.org/10.1016/j.chemosphere.2 011.11 .038

Srogi, K. (2007). Monitoring of environmental exposure to polycyclic aromatic hydrocarbons: A review. Environ. Chem. Lett. 5, 169-195. https://doi.org/10.1007/s10311-007-0095-0

Stracquadanio, M., Dinelli, E., Trombini, C. (2003). Role of volcanic dust in the atmospheric 
transport and deposition of polycyclic aromatic hydrocarbons and mercury. J. Environ. Monit. 5, 984-988. https://doi.org/10.1039/B308587B

Sulong, N.A., Latif, M.T., Sahani, M., Khan, M.F., Fadzil, M.F., Tahir, N.M., Mohamad, N., Sakai, N., Fujii, Y., Othman, M., Tohno, S. (2019). Distribution, sources and potential health risks of polycyclic aromatic hydrocarbons (PAHs) in $\mathrm{PM}_{2.5}$ collected during different monsoon seasons and haze episode in Kuala Lumpur. Chemosphere 219, 1-14. https://doi.org/10.1016/j.chemo sphere.2018.11.195

Syed, J.H., Iqbal, M., Zhong, G., Katsoyiannis, A., Yadav, I.C., Li, J., Zhang, G. (2017). Polycyclic aromatic hydrocarbons (PAHs) in Chinese forest soils: profile composition, spatial variations and source apportionment. Sci. Rep. 7, 2692. https://doi.org/10.1038/s41598-017-02999-0

Thornhill, D.A., Foy, B.D., Herndon, S.C., Onasch, T.B., Wood, E.C., Zavala, M., Molina, L.T., Gaffney, J.S., Marley, N.A., Marr, L.C. (2008). Spatial and temporal variability of particulate polycyclic aromatic hydrocarbons in Mexico City. Atmos. Chem. Phys. 8, 3093-3105. https://doi.org/10.5194/acp-8-3093-2008

Tobiszewski, M., Namieśnik, J. (2012). PAH diagnostic ratios for the identification of pollution emission sources. Environ. Pollut. 162, 110-119. https://doi.org/10.1016/j.envpol.2011.10.025

Tsapakis, M., Stephanou, E.G. (2005). Occurrence of gaseous and particulate polycyclic aromatic hydrocarbons in the urban atmosphere: Study of sources and ambient temperature effect on the gas/particle concentration and distribution. Environ. Pollut. 133, 147-156. https://doi.org/10.1016/j.envpol.2004.05.012

Unwin, J., Cocker, J., Scobbie, E., Chambers, H. (2006). An assessment of occupational exposure to polycyclic aromatic hydrocarbons in the UK. Ann. Occup. Hyg. 50, 395-403. https://doi.org/ 10.1093/annhyg/mel010

Velasco, E., Siegmann, P., Siegmannc, H. (2004). Exploratory study of particle-bound polycyclic aromatic hydrocarbons in different environments of Mexico City. Atmos. Environ. 38, 49574968. https://doi.org/10.1016/j.atmosenv.2004.05.020

Villalobos-Pietrini, R., Amador-Muñoz, O., Valle-Hernández, B., Gomez-Arroyo, S., Waliszewski, S. (2011). Organic compound in airborne particles and their genottoxic effects in Mexico City. Air Quality Monitoring, Assessment and Management. https://doi.org/10.5772/20500

Villalobos-Pietrini, R., Amador-Muñoz, O., Waliszewski, S., Hernandez-Mena, L., Munive-Colin, Z. Gomez-Arroyo, S., Bravo-Cabrera, J.L., Frias-Villegas, A. (2006). Mutagenicity and polycyclic aromatic hydrocarbons associated with extractable organic matter from airborne particles $\leq 10$ $\mu \mathrm{m}$ in southwest Mexico City. Atmos. Environ. 40, 5845-5857. https://doi.org/10.1016/j.atmo senv.2006.05.009

Wang, X.L., Tao, S., Dawson, R.W., Xu, F.L. (2002). Characterizing and comparing risks of polycyclic aromatic hydrocarbons in a Tianjin wastewater-irrigated area. Environ. Res. 90, 201-206. https://doi.org/10.1016/S0013-9351(02)00026-9

Wang, Y., Zhang, Q., Zhang, Y., Zhao, H., Tan, F., Wu, X., Chen, J. (2019). Source apportionment of polycyclic aromatic hydrocarbons (PAHs) in the air of Dalian, China: Correlations with six criteria air pollutants and meteorological conditions. Chemosphere 216, 516-523. https://doi.org/10.1016/j.chemosphere.2018.10.184

Weber, R., Kuch, B. (2003). Relevance of BFRs and thermal conditions on the formation pathways of brominated and brominated-chlorinated dibenzodioxins and dibenzofurans. Environ. Int. 29, 699-710. https://doi.org/10.1016/S0160-4120(03)00118-1

Westerdahl, D., Fruin, S., Sax, T., Fine, P.M., Sioutas, C. (2005). Mobile platform measurements of ultrafine particles and associated pollutant concentrations on freeways and residential streets in Los Angeles. Atmos. Environ. 39, 3597-3610. https://doi.org/10.1016/j.atmosenv.20 05.02 .034

Wilson, N.K., Barbour, R.K., Chuang, J.C., Mukind, R. (1994). Evaluation of a real-time monitor for fine-particle-bound PAH in air. Polycyclic Aromatic Compd. 5, 167-174. https://doi.org/10.10 80/10406639408015168

World Health Organization (2000). Air Quality Guidelines for Europe; WHO Regional Publications, European Series, No. 91; World Health Organization, Copenhagen.

Zhang, Y., Tao, S., Shen, H., Ma, J. (2009). Inhalation exposure to ambient polycyclic aromatic hydrocarbons and lung cancer risk of Chinese population. Proc. Natl. Acad. Sci. U.S.A. 106, 21063-21067. https://doi.org/10.1073/pnas.0905756106 